\title{
O direito das gentes e a nação: Do natural, positivo e possível
}

DOI: $10.15175 / 1984-2503-20179304$

\section{Gustavo Pinto de Sousa' ${ }^{1}$}

\begin{abstract}
Resumo
As reflexões aqui propostas têm como objetivo apresentar a literatura do direito das gentes. A questão problematizadora que tangenciará o texto serão os problemas internacionais gerados a partir do debate de supressão do tráfico de escravos, na primeira metade do século XIX. Isto é, como as nações brasileira, britânica e portuguesa buscaram no direito das gentes ferramentas de saber para justificar suas medidas políticas em relação ao tráfico internacional de escravos. Portanto, a análise de categorias do direito das gentes - natural, positivo e possível - formam quadros explicativos para as ações empreendidas na contenda estabelecida com a iminência de supressão do tráfico de escravos, da África para as Américas.
\end{abstract}

Palavras-chave: direito das gentes; tráfico internacional de escravos; nação; saber jurídico.

\section{El derecho de gentes y la nación: del natural, positivo y posible}

\section{Resumen}

Las reflexiones que aquí se proponen tienen por objeto presentar la literatura del derecho de gentes. La cuestión controvertida tangencial al texto son los problemas internacionales generados a partir del debate de supresión del tráfico de esclavos, en la primera mitad del siglo XIX, es decir, la manera en que las naciones brasileña, británica y portuguesa buscaron en el derecho de gentes herramientas del saber para justificar sus medidas políticas en relación con el tráfico internacional de esclavos. El análisis de categorías del derecho de gentes -natural, positivo y posible-forma cuadros explicativos de las acciones emprendidas en la contienda establecida ante la inminencia de supresión del tráfico de esclavos, de África a las Américas.

Palabras clave: Derecho de gentes; tráfico internacional de esclavos; nación; saber jurídico.

\section{Jus gentium and the nation: natural, positive, and possible}

\section{Abstract}

The reflections offered here aim to outline the literature on jus gentium (the law of nations), with a particular focus on the international challenges generated by the debate on the abolition of the slave trade in the first half of the nineteenth century. This refers to how Brazil, the United Kingdom, and Portugal turned to the law of nations for tools of knowledge in order to justify political measures taken in relation to the international slave

1 Professor de História na Universidade Federal do Oeste do Pará (UFOPA). Doutor em História pelo PPGHC/UFRJ. Mestre em História Política pelo PPGH/UERJ com bolsa Capes/DS. Foi Professor contratado do Colégio de Aplicação da UERJ/ CAp/UERJ e da Licenciatura em História da UERJ. Professor-tutor no curso de História da UNIRIO, pólo de Duque de Caxias. Pesquisador Associado do Laboratório de Estudo das Diferenças e Desigualdades Sociais -LEDDES/UERJ e Pesquisador do Laboratório de Estudos Africanos (LeÁfrica/UFRJ). E-mail: gsousarj@gmail.com 
trade. By analyzing the three categories of the law of nations - natural, positive, and possible - we form explanatory frameworks for the initiatives undertaken in the disputes established prior to the abolition of the trading of slaves from Africa to the Americas.

Keywords: Jus gentium; international slave trade; nation; legal knowledge.

\section{Le droit des gens et la nation: du naturel, positif et possible \\ Résumé}

Les réflexions ici proposées ont pour objectif de présenter la littérature du droit des gens. La mise en perspective qui oriente ce texte part des problèmes internationaux générés par le débat sur l'abolition de l'esclavage lors de la moitié du $\mathrm{XIX}^{\mathrm{e}}$ siècle, à savoir la manière dont les nations brésilienne, britannique et portugaise ont cherché dans le droit des gens des outils de savoir pour justifier leurs mesures politiques liées à la traite des esclaves. L'analyse des catégories du droit des gens - naturel, positif et possible - nous a permis d'ébaucher un cadre explicatif des actions entreprises au sein des conflits relatifs à l'imminence de l'abolition de la traite entre l'Afrique et les Amériques.

Mots-clés : Droit des gens ; traite des esclaves ; nation ; savoir juridique.

\section{民权和民族权：自然的, 实证的和可能的}

摘要

本文介绍了有䏌民权问题的参考文献, 并对此议题进行反思。所有民权问题的研究文献都可以追溯到 19 世纪 上半叶矢于禁止奴隶贸易的辩论所产生的一系列国际问题。巴西, 英国和葡萄牙三国政府都在民权法典中寻求 知识工具, 用来解释他们针对国际奴隶贩卖问题所采取的政治措施。通过对民权的范畴及其自然性, 实证性和 可能性进行了分析, 国际社会形成了自己的解释框架, 用于指导反奴隶贸易的斗争, 并采取实际行动。

矣键词：民权；国际奴隶贩运；民族；法律知识.

Semelhante sociedade tem suas próprias atividades e interesses; ela delibera e toma decisões em comum e com isso se torna uma pessoa jurídica que tem entendimento e vontade próprios, e que é capaz de obrigações e de direitos.

Emmerich von Vattel ${ }^{2}$

Em Direito das gentes, ao responder ao questionamento sobre o que era a nação ou um Estado, Vattel definia que o Estado ou a nação eram como "corpos políticos", ${ }^{3}$ e que em sua constituição havia uma demanda de homens reunidos em sociedade em um esforço de solidariedade, com o escopo de garantir a segurança e os benefícios de uma vida em comum. No entanto, ao qualificar a nação como corpo social, ele afirmava que ela era antes de mais nada uma "pessoa jurídica". Nesse sentido, apontou que as deliberações nacionais

\footnotetext{
2 VATTEL, Emer de. O direito das gentes. Brasília: UnB/Instituto de Pesquisas das Relações Internacionais, 2004. p. 1.

${ }^{3}$ Historiadores como Eric Hobsbawm e Benedict Anderson atentam que a nação foi resultado da formação dos Estados nacionais, que emergiram no final da Revolução Francesa e pelo século XIX. Entretanto, Vattel emprega o termo nação em um sentido político de Estado.
} 
eram normatizações e institucionalizações que afetavam a vida dos homens e das mulheres que constituem esse tecido político.

Esses "corpos políticos" foram compreendidos por Eric Hobsbawm ${ }^{4}$ como uma unidade política. Há nos "autores modernos" o emprego da palavra nação; no entanto, o autor marxista considerava que a nação, conforme conhecemos hoje, foi resultado da invenção dos Estados nacionais no século XIX. Ele sintetizou cinco pontos sobre o que era uma nação, sendo eles a prerrogativa da unidade política, os sentimentos protonacionais, ${ }^{5}$ as condições econômicas, as invenções das tradições e a ideia de uma consciência nacional, ou seja, a ideia de um pertencimento.

Essa personificação jurídica da nação na esteira do direito das gentes fez com que ela se tornasse responsável por suas ações no plano internacional. Em suma, além de legislar sobre as vontades de sua sociedade, com direitos e deveres, ela também precisava ser "capaz de obrigações e de direitos" para fora de seu espaço geográfico. Nesse sentido, Vattel permite afirmar que na relação entre direito das gentes e nação havia uma jurisprudência em respeitar a institucionalização jurídica que extrapolava as fronteiras nacionais com uma forma de harmonizar as convivências.

Para ele, a condição do direito tinha como desdobramento o cumprimento da obrigação. Assim, a partir do momento em que as nações se consideravam "pessoas jurídicas", deveria existir uma lei que orientasse essa jurisdição. O direito responsável por organizar essas complexas inter-relações estava amparado no direito natural. Em suas palavras: "a nação inteira, cuja vontade comum não é senão o resultado das vontades reunidas dos cidadãos, permanece submetida às leis da natureza, obrigada a respeitá-las em todos os seus atos". ${ }^{6}$

Se o respeito ao direito natural era a orientação a ser seguida no âmbito das relações internacionais, ela não seria exclusiva no intercâmbio entre as nacionalidades. Vattel reconhecia que o direito natural não era universal e aplicável por todos. Assim, o direito das gentes positivo era o fio condutor nas relações entre um Estado nacional e outro. Foi a partir dele que os tratados, convenções e acordos foram possíveis de ser realizados. Pois, como "pessoa jurídica", antes de controlar suas "paixões e vontades próprias", era

\footnotetext{
4 HOBSBAWM, Eric. Nações e nacionalismo desde 1780. Rio de Janeiro: Paz e Terra, 1990.

5 Benedict Anderson chama de "raízes culturais", e Ernest Renan, de sentimentos "pré-nacionais". Seriam eles: raça, língua, interesses, afinidades comuns, geografia e necessidades militares. Mas que sozinhos não explicam, nem dão conta do que seria a nação.

6 VATTEL, 2004, p. 2.
} 
necessário deliberar sobre uma vontade comum. Foi nesse ponto que emergiram as querelas envolvendo Brasil e Portugal contra a Inglaterra.

Na miscelânea entre direito das gentes, nação e tráfico de escravos, aplicar a noção de Vattel é um exercício jurídico complexo. No século XIX, do ponto de vista do direito natural, o tráfico de escravos era considerado desumano, pois retirava a qualidade "sagrada" da liberdade do ser humano. Vale ressaltar que nesses novos tempos de "direitos" a escravidão foi de legítima a amaldiçoada aos olhos dos filantropos, humanistas, alguns iluministas e abolicionistas. Contudo, o direito natural não foi suficiente para desarticular as redes do escravismo internacional.

Entrou em cena, portanto, o direito das gentes positivo. Os grupos contrários ao tráfico de escravos - quakers, abolicionistas, filantropos - , capitaneados, de início, pela Inglaterra, buscaram por meio de acordos bilaterais ou de convenções - "instrumentos jurídicos" - cercear o direito de transportar da África para a América os tumbeiros. Seu intuito era suprimir o "infame comércio" com uma forma de garantir o direito natural aos povos da África. Entretanto, essa campanha encontrou obstáculos em países como Brasil, Portugal e, por que não mencionar, Estados Unidos, Espanha e Cuba, que entenderam a medida como falta de reconhecimento das "nações abolicionistas" em não observar as atividades e os interesses próprios das nações.

Rafael Marquese e Tâmis Parron estudaram que as relações escravistas aproximaram Brasil, Estados Unidos e Cuba. A onda da "internacional escravista" 7 interlaçava as duas nações, mais a colônia espanhola, a partir do sentido que a escravidão tinha no meio social, ou seja, a força produtiva de suas economias acabou vinculando os interesses escravistas. Para eles, dois pontos uniam esses espaços geográficos nos problemas desdobrados entre a nação e os problemas do direito das gentes ou sistema interestatal, como denominam os autores. Em suas palavras:

[...] primeiro, o peso decisivo da escravidão negra em cada uma de suas ordenações políticas; segundo, o modo pelo qual a emergência do movimento

\footnotetext{
7 Para Marquese e Bivar, o conceito de segunda escravidão parte da definição do historiador Dale Tomich. Para eles, as experiências históricas dos Estados Unidos do Império do Brasil e de Cuba foram uma antítese da definição de "emancipações" que por um tempo classificaram-se no século XIX. Assim discorrem os autores: "Usualmente tomado como o século da emancipação, esse período verificou em realidade o apogeu da escravidão negra no Novo Mundo, tanto do ponto de vista do número absoluto de escravos alocados nas plantations americanas, como do valor obtido com a exploração do trabalho deles" (MARQUESE, Rafael de Bivar; PARRON, Tâmis Peixoto. Internacional escravista: a política da segunda escravidão. Topoi (Rio J.), Rio de Janeiro, v. 12, n. 23, p. 97-117, 2011. Cross ${ }^{\text {Ref. }}$ p. 99).
} 
antiescravista internacional — transformado em arma geopolítica pela Grã-Bretanha — condicionou os caminhos por eles seguidos. ${ }^{8}$

A "governabilidade da escravidão", ${ }^{9}$ portanto, fazia com que as nações escravistas criassem meios para perpetuar o tráfico intercontinental de escravos em detrimento da campanha do "abolicionismo internacionalista", ${ }^{10}$ que defendia uma política militar, a aplicação da tese de "solo livre" e da promoção das abolições no interior das nações.

Até agora, mencionaram-se as responsabilidades do direito natural e do direito positivo, como se o primeiro fosse um conjunto de regras básicas que nascem com 0 indivíduo e o segundo fosse forjado nos anseios da sociedade e nas relações de poder. Miguel Reale ${ }^{11}$ classificou o direito natural por duas vias, como "princípios inatos" de todos os homens ou como "princípios universais". Já o direito positivo, como um campo de saber orientado por convenções e regras.

Sobre a questão do que é o direito natural, o jurista Luís Roberto Barroso avaliou:

Sua ideia básica consiste no reconhecimento de que há, na sociedade, um conjunto de valores e de pretensões humanas legítimas que não decorrem de uma norma jurídica emanada do Estado, isto é, independem do direito positivo. Esse direito natural tem validade em si, legitimado por uma ética superior, e estabelece limites à própria norma estatal. ${ }^{12}$

Existe, portanto, entre os juristas, o reconhecimento de que certos direitos não passam pela investidura dos governos ou das formas jurídicas. Ou seja, algumas prerrogativas, como o direito à vida, à liberdade e à justiça, seriam os méritos de um direito natural. No entanto, esse reconhecimento do direito natural esboçado pelo atual ministro do Supremo como uma "ética superior" apresenta-se um tanto generalizada. O cerne do

\footnotetext{
8 MARQUESE; PARRON, 2011, p. 99.

${ }_{9}$ Marquese e Parron definem essa governabilidade da escravidão pelos arranjos políticos que eram condicionados pela cultura política, pela composição social e pela estrutura de governo de cada região. Assim, tanto o Congresso americano, o senhoriato cubano e o Legislativo brasileiro tinham redes do escravismo no cenário da política (MARQUESE; PARRON, 2011, p. 104).

$10 \mathrm{O}$ abolicionismo internacionalista consistia na condenação moral e jurídica do tráfico e da escravidão no plano internacional. Eles reuniam-se em congressos e convenções para firmar acordos na luta contra os apoiadores de uma "internacional escravista", como os fazendeiros sulistas, nos Estados Unidos, a elite cafeeira no Brasil e os canavieiros em Cuba.

11 REALE, Miguel. Filosofia do direito. São Paulo: Saraiva, 1999. Sobre direito natural: "o Direito Natural é um direito inerente à razão, como conjunto de 'princípios inatos' em todos os homens; outros, ao contrário, sustentam que não existem direitos inatos, assim como não há ideias inatas, mas apenas princípios universais que a razão elabora servindo-se dos elementos da experiência, transcendendo o plano da mera generalização, por um hábito racional que nos leva a querer o bem e a evitar o mal" (REALE, 1999, p. 97). Sobre direito positivo: "O Direito Positivo constitui-se, pois, com base no conjunto de regras e preceitos postos pelo legislador, pelos costumes, ou pela jurisdição e por convenções lícitas, e que, pelo simples fato de serem vigentes, devem ser havidos como obrigatórios" (REALE, 1999, p. 161).

12 BARROSO, Luís Roberto. Novo Direito Constitucional Brasileiro. Revista de Direito Administrativo, Rio de Janeiro, v. 225, p. 1-38, set. 2001, p. 18. Disponível em: <http://bibliotecadigital.fgv.br/ojs/index.php/rda/article/download/47562/44776>. Acesso em: 22 ago. 2015.
} 
problema de uma leitura jurídica do tráfico de escravos a partir do direito das gentes foi como as nações lidaram como uma noção de "ética superior que estava para além da norma estatal. Afinal, o que era uma ética contra a escravidão”, para o governo de Londres, não significava o mesmo para os governos de Lisboa e do Rio de Janeiro.

Em um estudo sobre a modernidade, Marshall Berman discutiu as visões de uma ética sobre o trabalho. Ele apresentou a análise de uma "ética negativa do trabalho" e de uma "ética positiva do trabalho". ${ }^{13}$ Na primeira, havia o peso da tradição e da ordem, na qual os indivíduos sabiam seu lugar. Além disso, a característica estamental e a hierarquia eram valores orquestrados e mantidos pela sociedade. Em linhas gerais, Brasil e Portugal compartilhavam desse sentido ao ativar as hierarquias da antítese ${ }^{14}$ da casagrande/sobrados com a senzala/rua ou da exploração ultramarina nas colônias portuguesas na África.

Já a "ética positiva do trabalho" emergiu a partir da divisão do trabalho. Para ele, nessa ética havia a expectativa da transformação pelo trabalho, podendo o homem e a sociedade alavancar melhores condições. ${ }^{15}$ A experiência das workhouses, na Inglaterra, considerava que ela seria uma forma de redenção. Há de se destacar que esse trabalho também explorou a incipiente classe operária na Grã-Bretanha. Com a diferença de que eles acreditavam - o governo e os industriais - que estavam operando uma forma de alavancar a dignidade humana.

Berman colocou como cerne dessa perspectiva a razão burguesa e liberal como motores da promoção do trabalho. Apesar de a sociedade oitocentista não ser totalmente burguesa e liberal, havia um investimento em um novo sentido do trabalho, por isso combater o tráfico de escravos fazia parte do abolicionismo internacionalista. Portanto, defender ou condenar o tráfico de escravos dependia do ponto que não prejudicasse a economia política dos governos.

${ }^{13}$ Cf. BERMAN, Marshall. Tudo que é sólido desmancha no ar: a aventura da modernidade. São Paulo: Companhia das Letras, 1998.

${ }^{14} \mathrm{~A}$ antítese casa-grande/sobrados e senzala/rua inspirou-se nos trabalhos de Gilberto Freyre e Ilmar Rohloff de Mattos, ao pensar a casa-grande e os sobrados como o espaço da "boa sociedade", enquanto a senzala ou a rua eram o universo da arraia miúda ou das classes perigosas, que necessitavam de vigilância e controle. Cf.: FREYRE, Gilberto. Casa-grande e senzala. São Paulo: Global, 2004; FREYRE, Gilberto. Sobrados e mocambos. 9. ed. Rio de Janeiro: Record, 1996; MATTOS, Ilmar Rohloff de. O tempo Saquarema: formação do Estado imperial. São Paulo: Hucitec, 1990.

${ }_{15}$ Os estudos de Max Weber também problematizam a ética positiva e negativa do trabalho. Ver: WEBER, Max. A ética protestante e o "espírito" do capitalismo. São Paulo: Companhia das Letras, 2004. 
Por outro lado, Norberto Bobbio ${ }^{16}$ esclarece as competências desses campos jurídicos. Para ele, o direito natural consiste em critérios como a universalidade, a imutabilidade no tempo, ${ }^{17}$ natura (da natureza), ratio - são as razões dos deveres morais —, o comportamento regulador maniqueísta, no qual o direito natural estabelece o que seria bom e mal, e, por fim, o valor das ações, no qual esse campo jurídico preza por aquilo que é bom.

Já o direito positivo tem em sua base jurídica a noção de particularidade, ou seja, valia apenas em algumas partes - o que, aplicado a esta leitura jurídica, funcionou na relação entre o direito das gentes e as políticas de supressão do tráfico internacional de escravos. Ademais, pressupunha mutabilidade como algo não finito. Seu terceiro critério resultava da expressão latina potesta populis - o poder ao povo —, que de forma próxima consistira na intermediação do reconhecimento das vontades e do controle delas. Isso coadunava com o quarto ponto definido por voluntas, no qual "o direito positivo é conhecido através de uma declaração de vontade alheia (promulgação)". ${ }^{18}$ Ademais, ele apresenta um comportamento regulador, assim como o direito natural. Entretanto, seu aspecto é pautado pela norma. Nas palavras de Bobbio, "assumem uma certa qualificação apenas porque foram disciplinados". ${ }^{19} \mathrm{E}$, portanto, ele também tem um valor das ações, só que estabelecido pelo princípio da utilidade, e não da bondade. O exemplo dessa utilidade foi destacado por Albuquerque ao lembrar que o direito das gentes positivo era útil, pois mediava a redação e a conquista dos tratados.

Se, nos manuais, o direito das gentes em muitos casos foi a aplicação do direito natural às nações, cabe analisar como os publicistas da época analisaram a questão. Além disso, Ferreira, Paiva e Albuquerque admitiram que, na impossibilidade de exercer o direito das gentes na primeira forma, as nações deveriam, portanto, mediar e arbitrar suas relações com base no direito positivo no plano internacional. Ou seja, dentro da metáfora do possível de ser feito nos tempos de paz.

Silvestre Pinheiro Ferreira entendia que a nação era composta pela vontade de viver juntos. Para ele, "a reunião em um só corpo de nação de certo he mister que haja acordo de vontades; mas não pra deixar de se unir ou para se separar, pois basta não estar de

\footnotetext{
${ }^{16}$ BOBBIO, Norberto. O positivismo jurídico: lições de filosofia do direito. São Paulo: Ícone, 1995.

17 Segundo Bobbio (1995, p. 22), "esta característica nem sempre foi reconhecida: Aristóteles, por exemplo, sublinha a universalidade no espaço, mas não acolhe a imutabilidade no tempo, sustentando que também o direito natural poder mudar no tempo".

${ }^{18}$ BOBBIO, 1995, p. 23.

$19 \mathrm{lbidem}$.
} 
accordo". ${ }^{20} \mathrm{O}$ texto de Ferreira, que foi publicado na França na primeira metade do século XIX, era muito próximo do que Ernest Renan publicaria no final do Oitocentos. Em conferência em 11 de março de 1882, na Sorbonne, ao responder a "o que é uma nação", ele replicava:

A nação é uma alma, um princípio espiritual. Constituem essa alma, esse princípio espiritual, duas coisas que, para dizer a verdade, são uma só. Uma delas é a posse em comum de um rico legado de lembranças; a outra, o consentimento atual, o desejo de viver juntos, a vontade de continuar a fazer valer a herança que recebemos indivisa. ${ }^{21}$

O "acordo de vontades" de Ferreira entrecruza-se com "a vontade de continuar a fazer valer a herança" de Renan. O autor francês refinou o debate sobre o que é ser uma nação por ocasião dos conflitos de nacionalidade provenientes da Guerra Francoprussiana, em 1871. Assim, qualificava a nação como uma "grande solidariedade" e um "plebiscito cotidiano", pois, para viver juntos, era preciso também esquecer alguns fatos juntos. Isto é, "[...] uma nação é que todos os indivíduos tenham muito em comum, e também que todos tenham esquecido muitas coisas". ${ }^{22}$

Não há em Renan um cuidado com o direito das gentes. No entanto, em sua aula havia uma preocupação com o destino das "gentes". Ele afirmou que o "homem não é escravo de sua raça, nem de sua língua [...] nem da direção das cadeias de montanhas". ${ }^{23}$ Ele orientava que, quando um território estivesse sob contenda jurídica, que as "populações disputadas" fossem consultadas. Do ponto de vista filosófico, no qual Renan tem seu "lugar de fala", era uma condição legítima, mas impraticável para o período estudado. No exame dos juristas, não se tratava de dar vozes às populações. Transformar a nação em uma persona jurídica homogeneizava seus interesses e vontades no plano internacional, ou criava os "estatutos de verdade", ${ }^{24}$ conforme propunha Michel Foucault.

Vicente Ferrer Neto Paiva transformou a nação em uma "pessoa moral" ou "seres coletivos", que eram governados por soberanos e que não admitiam superior comum sobre a Terra. É interessante que ele vai vincular a noção de nação à de soberania em uma forma de imbricar os governos e seus negócios estrangeiros. A par disso, Paiva apontou: "a nação

\footnotetext{
${ }^{20}$ FERREIRA, Silvestre Pinheiro. Manual do cidadão em um governo representativo, ou princípios de direito constitucional, administrativo e das gentes. Paris: Rey et Gravier/J. P. Aillaud, 1834. v. 2, p. 514.

${ }^{21}$ RENAN, Ernest. O que é uma nação?. In: ROUANET, Maria Helena. Nacionalidade em questão. Rio de Janeiro, 1997. p. 39. Cadernos da Pós de Letras.

22 RENAN, 1997, p. 20.

23 Ibidem, p. 43.

${ }^{24}$ Em Foucault, o estatuto de verdade consiste na verdade como norma. Ao longo de seus trabalhos, o filósofo-historiador procura discutir como as condições históricas, econômicas e culturais propiciaram a consolidação dessas "verdades" discursivas.
} 
é uma associação d'homens, reunidos para melhor conseguirem os seus fins racionaes debaixo d'um superior commum, que se chama soberano ou governo. E que a representa em frente das outras nações". ${ }^{25}$

Para ele, a nação é um corpo político configurado a partir do governo. Em uma visão panorâmica da documentação relativa aos debates parlamentares, Brasil, Inglaterra e Portugal utilizaram essa definição de nação para organizar a dinâmica de seus interesses sobre a escravidão. Todavia, a definição de Paiva lembra que a soberania de uma nação era exclusiva "sobre a Terra". Assim, não cabia os mares, ou melhor, os oceanos não constituíam prerrogativa nacional e jurídica de nenhum soberano ou governo.

Sobre a correlação entre nação e soberania, o autor apontava que esses fatores garantiam a independência entre elas e a necessidade do respeito mútuo como forma de manutenção da harmonia e da paz. Nesse passo:

Uma nação, por mais numerosa e poderosa que seja, não tem naturalmente, como pessoal moral, mais direitos, nem obrigações, do que outra, ainda que mais pequena e fraca; porque ambas ellas são compostas d'homens, que gozam do direito absoluto d'independência. A força não é medida do Direito e nem produz direito. O número das pessoas, que constituem um ser collectivo, não altera os seus direitos; bem como a diferença da extensão de dois círculos não muda suas propriedades essencialmente communs. ${ }^{26}$

Esse ensinamento de Paiva aquece o estado da questão: a governamentalidade. Há no texto um sentido de preocupação com a economia política dos governos e, consequentemente, a gestão de suas riquezas, que devem ocorrer sem prejuízo de outra nação. A Inglaterra, na condição de nação rica e poderosa, não teria mais direitos do que Brasil e Portugal ao impor restrição de direitos para ambas. Os bills Palmerston e Aberdeen, do ponto de vista jurídico, estavam em clara desorientação às regras do direito das gentes de caráter voluntário (Vattel), filosófico (Paiva e Pinheiro) ou natural (Albuquerque). Isso nos permite afirmar que o que foi levado em consideração no tribunal das contendas era um direito das gentes positivo, no qual as nações negociavam entre si com acordos e tratados, e que nem sempre consideravam que o direito positivo aplicado ao direito das gentes poderia ser particular, mutável e disciplinado, confirmando a hipótese de que o tráfico de escravos ativou uma discussão internacional sobre o direito das gentes. E como sua utilização tornou-se instrumento político-jurídico na defesa dos interesses nacionais e da economia política.

${ }^{25}$ PAIVA, Vicente Ferrer Neto. Elementos de direito das gentes. Lisboa: Universidade de Coimbra, 1839. p. 2. 26 Ibidem, p. 5-6. 
Pedro Autran da Malta Albuquerque fez uma relação entre nação e gente. Segundo ele: "o gênero humano divide-se em grupos, mais ou menos consideraveis, reunidos pela mór parte em associação civil para o fim de segurança interna e externa. Estes grupos compõem as diferentes nações da terra, que são consideradas como outras tantas individualidades". ${ }^{27}$

O jurista brasileiro, assim como seus pares portugueses, também compartilhava da noção de nação como um corpo. Em Albuquerque, esse corpo formado pelas "gentes" era o que dava sentido ao nacional. A relação entre a nação e o direito das gentes era pautada quando a primeira era responsável pela organização civil (direito público interno), e que, a posteriori, seria utilizada como ferramenta de relação com as demais nações, o que constituiria, paulatinamente, o direito público externo.

Em um caráter pragmático sobre a distinção dos direitos das nações e dos indivíduos, ele destacava que ambos estavam fixados nos mesmos princípios e que era possível estabelecer "verdades morais". Seriam elas:

1ㅇ Todo o ente moral, quer seja individuo, quer nação, tem o direito de se conservar, aperfeiçoar, e promover a sua felicidade. 20 Ninguem pode locupletar-se, nem avantajar-se com lesão do direito de outro; 3o Quem lesa o direito alheio está obrigado a reparação; 40 as convenções livremente feitas entre pessoas capazes de contractar, e sobre objeto licito, ligão as partes contractantes. ${ }^{28}$

As "verdades morais" de Albuquerque seriam os preceitos de como as diferentes gentes das nações deveriam se comportar em suas negociações. O princípio benthamiano de "felicidade" levava em consideração que entre os governos deveria existir o princípio de não intervir nos assuntos dos outros. Em linhas gerais, a primeira regra era um desenrolar para os outros pontos, no qual o enriquecimento pela desgraça do outro e a ruína econômica deveriam ser combatidos na relação entre as gentes e as nações. E o que será analisado em fontes específicas era que os governos das nações brasileira e portuguesa reclamavam e protestavam que os bills promoviam, justamente, o que Albuquerque indicava em seus três primeiros pontos. Isto é, para os brasileiros, a política britânica não promovia o respeito aos direitos e conduzia à ruína da "Grande Lavoura", que dependia da mão de obra africana. Os portugueses, por sua vez, acusavam a Inglaterra de deteriorar as

${ }^{27}$ ALBUQUERQUE, Pedro Autran da Malta. Elementos do direito das gentes. Pernambuco: Tipografia União, 1851. p. 3.

28 lbidem, p. 4. 
condições econômicas de suas colônias e da sede do Império, locupletando-se à revelia do governo de Lisboa.

Os "coletivos" e os "grupos" de Paiva e Albuquerque, respectivamente, recordam o livro Comunidades imaginadas, de Benedict Anderson. Para ele, uma nação é "uma comunidade política imaginada - e imaginada como sendo intrinsecamente limitada e, ao mesmo tempo, soberana". ${ }^{29}$ Existe na nação um exercício em transformar aquilo que é heterogêneo na homogeneidade nacional. Isto é, as raízes culturais, como raça, língua, interesses locais, afinidades religiosas, geografia e as questões militares precisam ser equacionadas para se pensar a nação.

As "amnésias do nacionalismo", ${ }^{30}$ como propôs Lilia Moritz Schwarcz, aproximamse da ideia de Renan de que, para se estar junto, é preciso esquecer. E essa comunidade justificava-se, portanto, independentemente das diferenças e das desigualdades de seu interior. No plano internacional, o que importava era a "camaradagem horizontal", isto é, unificar os desejos e as paixões diferenciados sob a égide de uma bandeira soberana. Assim, na cena mundial, criou-se ser brasileiro ou português como sinônimo de escravista, enquanto o ser britânico associou-se ao combate ao ilícito comércio e à antiescravidão. Enquanto ao primeiro inventou-se uma veracidade, ao segundo era questionada a experiência britânica com os chineses após a Guerra do Ópio, contestando se de fato existia ali um combate à escravidão.

Por essas regras, o que a sanção dos bills promoveu entre os envolvidos foi o princípio do quarto ponto - "as convenções livremente feitas entre pessoas capazes de contractar, e sobre objeto licito, ligão as partes contractantes". ${ }^{31}$ De fato, as convenções ligaram as partes contratantes. O problema era que uma das partes - Brasil e Portugal nunca desejou contratar os bills. O que foi feito, então, era redigir um novo projeto jurídico entre ambas, com um texto que garantisse a promoção da felicidade dos indivíduos e da nação, atribuindo, portanto, o sentido jurídico de ligação das partes contratantes. ${ }^{32}$

\footnotetext{
29 ANDERSON, Benedict. Comunidades imaginadas: reflexões sobre a origem e a difusão do nacionalismo. São Paulo: Companhia das Letras, 2008. p. 32.

30 Ibidem.

${ }^{31}$ ALBUQUERQUE, 1851. p. 4.

32 FREITAS, Pedro Manuel Luís. O ultramar português na época do setembrismo: um caso de nacionalismo económico. In: PASSOS MANUEL E O LIBERALISMO: SANTARÉM E O PRONUNCIAMENTO NACIONAL DE 1846, 1996, Santarém. Actas... Santarem: Escola Superior de Educação de Santarém, 1996. p. 83-92. p. 83. Segundo Pedro Manuel Luís de Freitas, "a vitória do cartismo levou em 1842 à celebração de um tratado sobre a abolição do tráfico de escravos entre Portugal e Inglaterra". Já segundo Paulo Roberto de Almeida, "a Lei Aberdeen, contudo, foi revogada pelo Parlamento britânico apenas em 1869, numa conjuntura de
} 
Falou-se muito em direito natural, das gentes e das nações, principalmente, no último caso, das nações brasileira, britânica e portuguesa. E marginalizaram-se as "gentes" africanas, que na ocasião eram os defendidos pela campanha dos filantropos e do abolicionismo internacional. Onde inserir os africanos escravizados no processo de construção/invenção da nação e em sua relação com o direito das gentes? Essa inserção foi complicada, porque eles ficaram à margem do sentimento da nacionalidade. Sem esquecer de mencionar a vulnerabilidade na construção da cidadania.

Homi Bhabha, em uma via pós-colonialista, estudou o "entrelugar"33 daqueles que não eram identificados com os projetos de nação. No caso dos africanos e das africanas retirados da África e escravizados, esses "entrelugares" seriam quando sua identidade de ligação com a territorialidade e a cultura política perdesse seu primeiro sentido, enquanto sua nova orientação na condição de escravos não permitisse interação com a nova realidade. Interação essa no que tange ao sentimento de integrar a nação. Seu contato era distinto, ocorria a partir do mundo do trabalho. Em suma, os entrelugares de Bhabha ocorrem quando uma identificação já não é mais a mesma, nem nova ao mesmo tempo. ${ }^{34}$ Para ele:

A nação preenche o vazio deixado pelo desenraizamento de comunidades e parentescos, transformando esta perda na linguagem da metáfora. A metáfora, como sugere a etimologia da palavra, transporta o significado casa e de sentir em casa através da meia-passagem ou das estepes da Europa Central, através daquelas distâncias culturais, que transpõem a comunidade imaginada do povonação. ${ }^{35}$

Ele, ao trabalhar a imagem dos imigrantes e refugiados, questionava-se qual seria o lugar que esses homens, mulheres e crianças assumiam nas novas nações para a qual se dirigiam. Ao dialogar com Bhabha, a condição dos africanos ilegalmente escravizados era muito próxima. Pois a eles era negado, além do direito a viver a nacionalidade, impensável

conciliação de interesses entre os dois países". ALMEIDA, Paulo Roberto de. Formação da Diplomacia Econômica no Brasil: as relações internacionais no império. Brasília: Funag, 2005, p. 343.

${ }^{33}$ Para Bhabha (1998, p. 20): "Esses 'entrelugares' fornecem terreno para a elaboração de estratégias de subjetivação - singular ou coletiva - que dão início a novos signos de identidade e postos inovadores de colaboração e contestação, no ato de definir a própria ideia de sociedade. É na emergência dos interstícios - a sobreposição de domínios da diferença - que as experiências intersubjetivas e coletivas de nação [nationness], o interesse comunitário ou o valor cultural são negociados".

${ }^{34}$ Stuart Hall e Néstor Canclini chamariam esse fenômeno de "hibridismo ou hibridismo cultural". Hall (2003, p. 49), por exemplo, considera que "a nação não é apenas uma entidade política, mas algo que produz sentidos". Para ele, os ideais homogeneizantes da nação são ensinados, formados e transformados nos indivíduos.

35 BHABHA, 1998, p. 199. 
para o período, com ressalvas ao processo de independência do Haiti, comandado por negros no início do século XIX. ${ }^{36}$

Bhabha reconhece os estudos de Hobsbawm e Anderson, mas seu objetivo seria compreender a localidade das culturas na contraposição da comunidade. Seu estudo problematiza a nação como uma força narrativa e psicológica, e não apenas como uma categoria sociológica ou empírica. Para ele, portanto, a nação é mais do que o culto ao passado eleito e inventado ou a uma cartilha pedagógica. A narrativa de uma nação consiste, em suma, em considerar também os homens e as mulheres dos entrelugares. ${ }^{37}$

Em trabalho anterior, ${ }^{38}$ o governo brasileiro propunha a compra de um território, na África, para o envio dos africanos livres que oneravam a Fazenda Real. Na ocasião, a ideia brasileira inspirava-se na experiência dos Estados Unidos, com a compra da Libéria. A aquisição da Libéria ${ }^{39}$ decorreu da iniciativa tomada no século XIX pelos norte-americanos, que construíram na costa ocidental da África um território constituído por escravos libertos nos Estados Unidos. Sua formação foi oriunda da iniciativa da Sociedade Americana de Colonização, que levou para a África negros livres ou alforriados da escravidão. O incentivo para a construção desse território foi motivado pelo fato de os africanos que gozavam de liberdade não serem integrados à sociedade norte-americana. A fim de evitar sua ociosidade e marginalidade, era mais vantajoso construir um lugar na África.

Entretanto, o governo brasileiro barrou a iniciativa com três justificativas: primeiro, porque a ausência da mão de obra africana no país geraria um colapso na produção; segundo, o governo não tinha receitas disponíveis para tamanho empreendimento; e, depois, o governo brasileiro já contava com a utilização da mão de obra dos africanos livres para garantir os "serviços pesados" — labor — das e nas instituições públicas. ${ }^{40}$

\footnotetext{
${ }^{36}$ Sobre a independência do Haiti, ver: BLACKBURN, Robin. A queda do escravismo colonial, 1776-1848. Rio de Janeiro: Record, 2002; MOREL, Marco. O abade Grégoire, o Haiti e o Brasil: repercussões no raiar do século XIX. Almanack Braziliense, São Paulo, n. 2, p. 76-90, nov. 2005. Cross Ref.

${ }^{37}$ Assim como Bhabha, Stuart Hall e Paul Gilroy, no que tange à cultura negra nos distintos espaços americanos, questionaram a "essencialização" do ser africano nas Américas. Para eles, esses grupos humanos constituíram uma identidade nacional que não é essencialmente africana, e aqui na América a (res)significaram com suas singularidades. Cf. HALL, Stuart. Da diáspora, identidades e mediações culturais. Belo Horizonte: Humanitas, 2003; GILROY, Paul. Atlântico Negro: modernidade e dupla consciência. Rio de Janeiro: Ed. 34, 2001.

38 SOUSA, Gustavo Pinto de. Africanos livres: escravos, prisioneiros ou trabalhadores da Casa de Correção da Corte?. Rio de Janeiro: Multifoco, 2013.

${ }_{39} \mathrm{Em} 1824$, a faixa de terra comprada pelos Estados Unidos na África passou a ser denominada Libéria, cujo sentido era "terra livre".

40 No relatório ministerial da Justiça, em 1834, o ministro liberal Manoel Alves Branco apresentava à Assembleia uma ideia de que o governo adquirisse uma faixa de terra na África para retornar com os africanos considerados livres após a lei de 1831. Em suas palavras: "O Governo pois espera do patriotismo, liberalidade, e espirito religioso dos Membros desta Augusta Assembléa, que nesta Sessão Ihe seja facultado hum credito
} 
Portanto, o que se averiguou da relação entre o direito das gentes e a nação era que o primeiro concedia suporte para a segunda na administração de seus interesses nacionais. O direito das gentes instruía a nação de que ela tinha direitos e obrigações a cumprir no jogo das relações internacionais. E quando o assunto era a escravidão e o tráfico de escravos, Marquese e Parron salientavam que "a escravidão negra oitocentista como instituição era regulada no plano nacional, mas condicionada no internacional". ${ }^{41}$

Em suma, internamente, a escravidão era legítima do ponto de vista do direito público interno, entretanto, do ponto de vista do direito público externo - das gentes, interestatal ou internacional —, emergia uma campanha para desarticulá-la. Isso, em muitos casos, feriu o princípio de soberania e do "acordo de vontades" daqueles que desejavam estar juntos, mesmo com os altos custos da escravidão.

\section{Referências}

ANDERSON, Benedict. Comunidades imaginadas: reflexões sobre a origem e a difusão do nacionalismo. São Paulo: Companhia das Letras, 2008.

ALBUQUERQUE, Pedro Autran da Malta. Elementos do direito das gentes. Pernambuco: Tipografia União, 1851.

ALMEIDA, Paulo Roberto de. Formação da Diplomacia Econômica no Brasil: as relações internacionais no império. Brasília: Funag, 2005.

BARROSO, Luís Roberto. Novo Direito Constitucional Brasileiro. Revista de Direito Administrativo, Rio de Janeiro, v. 225, p. 1-38, set. 2001. Disponível em: <http://bibliotecadigital.fgv.br/ojs/index.php/rda/article/download/47562/44776>. Acesso em: 22 ago. 2015.

BERMAN, Marshall. Tudo que é sólido desmancha no ar: a aventura da modernidade. São Paulo: Companhia das Letras, 1998.

BHABHA, Homi. O local da cultura. Belo Horizonte: UFMG, 1998.

especial para a criação na Africa de hum estabelecimento semelhante á Liberia dos Americanos do Norte, que me parece o mais útil por outros muitos destinos, que se lhe pode dar." Cf. Arquivo Nacional. IJ7-1. Série Justiça. Relatórios dos ministros da Justiça, ano 1834. p. 8. Encontra-se também disponível em: <http://www.crl.edu/brazil/ministerial>.

41 MARQUESE; PARRON, 2011, p. 98. 
BLACKBURN, Robin. A queda do escravismo colonial, 1776-1848. Rio de Janeiro: Record, 2002.

BOBBIO, Norberto. O positivismo jurídico: lições de filosofia do direito. São Paulo: Ícone, 1995.

FERREIRA, Silvestre Pinheiro. Manual do cidadão em um governo representativo, ou principios de direito constitucional, administrativo e das gentes. Paris: Rey et Gravier/J. P. Aillaud, 1834. v. 2.

FREITAS, Pedro Manuel Luís. O ultramar português na época do setembrismo: um caso de nacionalismo económico. In: PASSOS MANUEL E O LIBERALISMO: SANTARÉM E O PRONUNCIAMENTO NACIONAL DE 1846, 1996, Santarém. Actas... Santarem: Escola Superior de Educação de Santarém, 1996. p. 83-92.

FREYRE, Gilberto. Casa-grande e senzala. São Paulo: Global, 2004.

FREYRE, Gilberto. Sobrados e mocambos. 9. ed. Rio de Janeiro: Record, 1996.

GILROY, Paul. Atlântico Negro: modernidade e dupla consciência. Rio de Janeiro: Ed. 34, 2001.

HALL, Stuart. Da diáspora, identidades e mediações culturais. Belo Horizonte: Humanitas, 2003.

HOBSBAWM, Eric. Nações e nacionalismo desde 1780. Rio de Janeiro: Paz e Terra, 1990.

MARQUESE, Rafael de Bivar; PARRON, Tâmis Peixoto. Internacional escravista: a política da segunda escravidão. Topoi (Rio J.), Rio de Janeiro, v. 12, n. 23, p. 97-117, 2011. Cross ${ }^{\text {Ref. }}$

MATTOS, Ilmar Rohloff de. O tempo Saquarema: formação do Estado imperial. São Paulo: Hucitec, 1990.

MOREL, Marco. O abade Grégoire, o Haiti e o Brasil: repercussões no raiar do século XIX. Almanack Braziliense, São Paulo, n. 2, p. 76-90, nov. 2005. Cross Ref.

PAIVA, Vicente Ferrer Neto. Elementos de direito das gentes. Lisboa: Universidade de Coimbra, 1839.

REALE, Miguel. Filosofia do direito. São Paulo: Saraiva, 1999.

RENAN, Ernest. O que é uma nação?. In: ROUANET, Maria Helena. Nacionalidade em questão. Rio de Janeiro, 1997. p. 39. Cadernos da Pós de Letras.

SOUSA, Gustavo Pinto de. Africanos livres: escravos, prisioneiros ou trabalhadores da Casa de Correção da Corte?. Rio de Janeiro: Multifoco, 2013.

VATTEL, Emer de. O direito das gentes. Brasília: UnB/Instituto de Pesquisas das Relações Internacionais, 2004. 
Passagens. Revista Internacional de História Política e Cultura Jurídica

Rio de Janeiro: vol. 9, no. 3, setembro-dezembro, 2017, p. 446-461.

WEBER, Max. A ética protestante e o "espírito" do capitalismo. São Paulo: Companhia das Letras, 2004. 